\title{
An insight into the mechanisms of COVID-19, SARS-CoV2 infection severity concerning $\beta$-cell survival and cardiovascular conditions in diabetic patients
}

\author{
Abhay Srivastava $^{1} \cdot$ Cheryl Rockman-Greenberg $^{2} \cdot$ Niketa Sareen $^{1,3} \cdot$ Vincenzo Lionetti $^{3} \cdot$ Sanjiv $^{\text {Dhingra }}{ }^{1}$ (D)
}

Received: 15 September 2021 / Accepted: 16 February 2022 / Published online: 2 March 2022

(c) The Author(s), under exclusive licence to Springer Science+Business Media, LLC, part of Springer Nature 2022

\begin{abstract}
A significantly high percentage of hospitalized COVID-19 patients with diabetes mellitus (DM) had severe conditions and were admitted to ICU. In this review, we have delineated the plausible molecular mechanisms that could explain why there are increased clinical complications in patients with DM that become critically ill when infected with SARS-CoV2. RNA viruses have been classically implicated in manifestation of new onset diabetes. SARS-CoV2 infection through cytokine storm leads to elevated levels of pro-inflammatory cytokines creating an imbalance in the functioning of T helper cells affecting multiple organs. Inflammation and Th1/Th2 cell imbalance along with Th17 have been associated with DM, which can exacerbate SARS-CoV2 infection severity. ACE-2-Ang-(1-7)-Mas axis positively modulates $\beta$-cell and cardiac tissue function and survival. However, ACE-2 receptors dock SARS-CoV2, which internalize and deplete ACE-2 and activate Reninangiotensin system (RAS) pathway. This induces inflammation promoting insulin resistance that has positive effect on RAS pathway, causes $\beta$-cell dysfunction, promotes inflammation and increases the risk of cardiovascular complications. Further, hyperglycemic state could upregulate ACE-2 receptors for viral infection thereby increasing the severity of the diabetic condition. SARS-CoV2 infection in diabetic patients with heart conditions are linked to worse outcomes. SARS-CoV2 can directly affect cardiac tissue or inflammatory response during diabetic condition and worsen the underlying heart conditions.
\end{abstract}

Keywords Diabetes $\cdot$ COVID-19 $\cdot$ SARS-CoV2 $\cdot \beta$-Cell death $\cdot$ Disease severity $\cdot$ Treatment

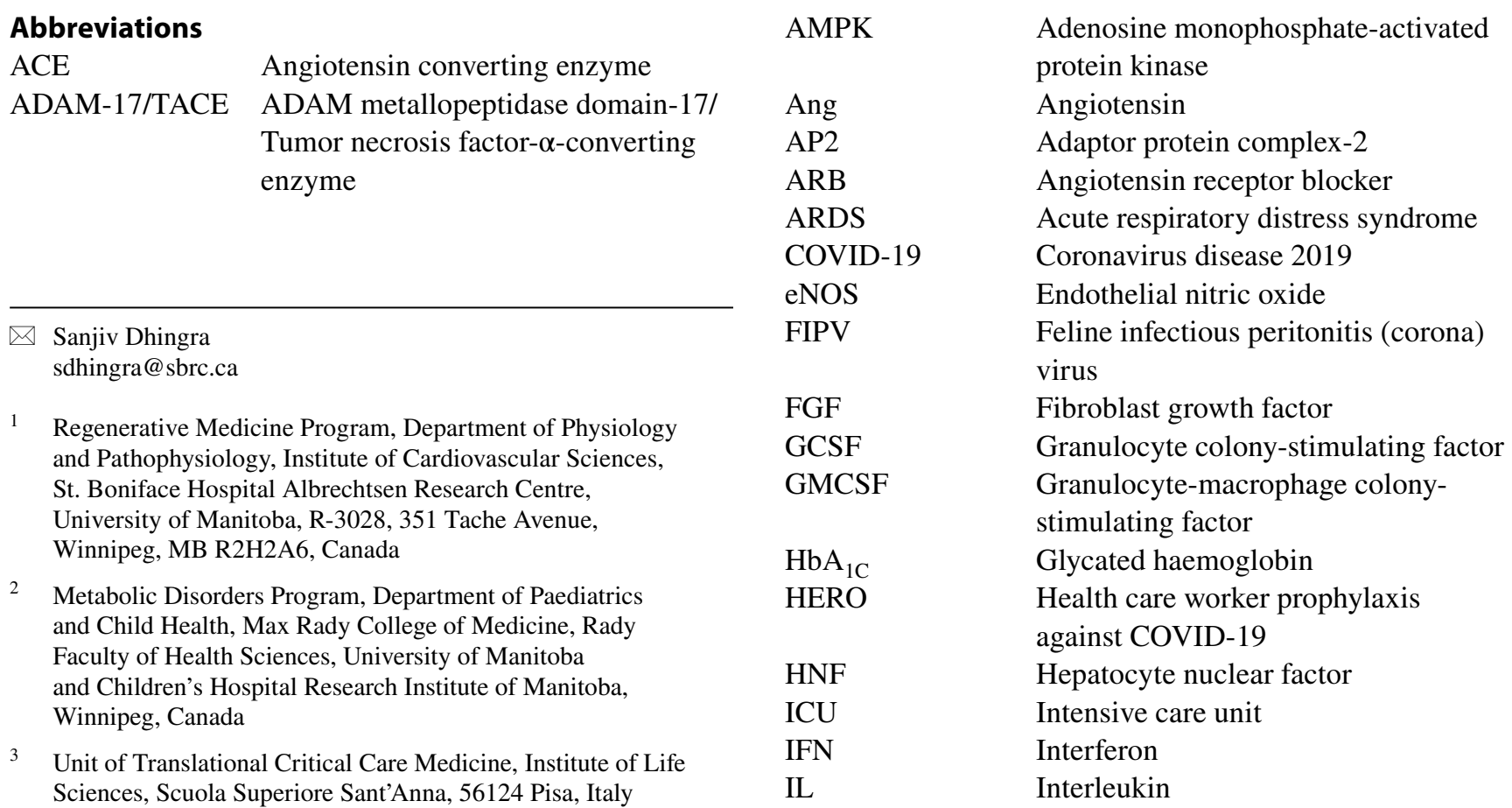




$\begin{array}{ll}\text { IP } & \text { Interferon gamma-induced protein } \\ \text { JAK } & \text { Janus kinases } \\ \text { MAS } & \text { Macrophage activation syndrome } \\ \text { Mas } & \text { MAS proto-oncogene } \\ \text { MCP } & \text { Monocyte chemoattractant protein } \\ \text { MERS-CoV } & \begin{array}{l}\text { Middle eastern respiratory syndrome } \\ \text { coronavirus }\end{array} \\ \text { MHC } & \text { Major histocompatibility complex } \\ \text { MIP } & \text { Macrophage inflammatory protein } \\ \text { mTOR } & \text { Mammalian target of rapamycin } \\ \text { NAD(P)H } & \text { Nicotinamide adenine dinucleotide } \\ & \text { (phosphate)-reduced form } \\ \text { NO } & \text { Nitric oxide } \\ \text { NOD } & \text { Non-obese diabetic } \\ \text { PDGF } & \text { Platelet derived growth factor } \\ \text { RAS } & \text { Renin-angiotensin system } \\ \text { RECOVERY } & \text { Randomized evaluation of COVID-19 } \\ & \text { therapy } \\ \text { SARS-CoV } & \text { Severe acute respiratory syndrome } \\ \text { T regs } & \text { coronavirus } \\ \text { Th } & \text { T regulatory cells } \\ \text { TMPRSS2 } & \text { T helper cells } \\ \text { TNF } & \text { Transmembrane protease, serine-2 } \\ \text { VEGF } & \text { Tumor necrosis factor } \\ & \text { Vascular endothelial growth factor }\end{array}$

\section{Background}

\section{Prevalence of diabetes and cardiovascular complications in COVID-19}

Diabetes mellitus (DM) is a collection of metabolic disorders characterized by hyperglycaemia resulting from defects in insulin secretion, action or both, owing to disturbance in carbohydrate, fat and protein metabolism. Long standing poorly controlled DM results in complication of eyes, kidneys, nerves, blood vessels and heart [1]. Current statistics by the international diabetes federation atlas 2019 project that nearly 463 million or $9.3 \%$ of adults worldwide have diabetes, which may ascend to 700 million or one in every ten adults by 2045 [2].

The outbreak of SARS-CoV-2, COVID-19 has seen successive epicenters that initiated from China to Europe to North America and followed by its progession to developing countries like Brazil and India. The pandemic started in China and in a comprehensive report of 138 patients hospitalized in the Wuhan district, a trend was observed where $22.2 \%$ and $25 \%$ of all patients requiring admission to intensive care units (ICU) were having diabetes and cardiovascular disease, respectively [3]. Similar data from Shanghai China reported $19.2 \%$ cases with critical pneumonia had diabetes and $30.8 \%$ had heart conditions [4]. In more recent reports; first originating from Wuhan, Hubei, China, 24.9\% of cases with severe COVID-19 symptoms were diabetic out of 193 critical patients and $27.1 \%$ of these patients with SARS-CoV2 infection had cardiovascular disease, which was significantly higher than non-diabetic patients [5]. A second report from Taizhau, Zhejiang, China reported 16.3\% diabetic patients among the severely ill COVID-19 patients, where $60.5 \%$ patients presented chest tightness as one of their symptoms [6]. The major epicenter of this outbreak in the European Union was at Italy. In one of the early reports in February from Pavia, Italy, 15.9\% and 25\% COVID-19 positive cases were patients with diabetes and heart disease, respectively [7]. Another report coming from the Lombardi region in Italy suggested that out of 1591 COVID-19 positive cases with critical symptoms requiring ICU admission, $17 \%$ were diabetic patients and $21 \%$ patients had cardiovascular disease [8]. Among all the fatalities in Italy a random number of 355 cases were screened for their comorbidities, and $126(35.5 \%)$ were observed to have diabetes and 30\% had ischemic heart disease [9]. The most alarming epicenter originated at USA where a recent report based from the city of New York, of 5700 COVID-19 positive patients who were hospitalized, 1808 , i.e. $33.8 \%$ patients were found to have diabetes and approximately $56.6 \%$ patients were having hypertension and $18 \%$ with other heart diseases [10]. A hospitalization surveillance network for the month of March 2020 in the USA found a total of $28.3 \%$ diabetic patients and $27.8 \%$ with cardiovascular disease in their cohort of hospitalized COVID-19 positive cases [11] (Tables 1 and 2). Similar reports have been emerging from many other affected regions throughout the globe.

\section{Immune imbalance and inflammation are direct effectors of deteriorating $\beta$-cell survival and cardiovascular conditions in diabetes}

\section{Viral infections as an environmental factor causing diabetes}

Viral infections are categorized as one of the main environmental factors in developing type $1 \mathrm{DM}$. There have been many RNA viruses that are reported to be associated with the development of type $1 \mathrm{DM}$ in humans. Coxsackie A/B viruses, Rubella viruses, Retrovirus and Rota viruses are among the reported viruses [12]. Previous studies have demonstrated that viral infections in $\beta$-cells cause prolonged presence of viral proteins within these cells. Also, $\beta$-cells have decreased defensive capacity against viral infections when compared to other neighboring endocrine cells. When these viral protein antigens mixed with $\beta$-cell specific antigens are presented to the host immune system, the generated 
Table 1 Prevalence of diabetes mellitus as a comorbidity in Covid-19 positive cases globally

\begin{tabular}{|c|c|c|c|c|c|c|c|c|c|}
\hline Report & {$[3]$} & [4] & {$[5]^{*}$} & {$[6]^{\#}$} & [7] & [8] & [9] & [10] & {$[11]$} \\
\hline Region & Wuhan, China & Hubei, China & Wuhan, China & $\begin{array}{l}\text { Taizhou, } \\
\text { Zhejiang, } \\
\text { China }\end{array}$ & $\begin{array}{l}\text { Pavia, North } \\
\text { Italy }\end{array}$ & $\begin{array}{l}\text { Lombardy. } \\
\text { Italy }\end{array}$ & Italy & $\begin{array}{l}\text { New York, } \\
\text { USA }\end{array}$ & $\begin{array}{l}\text { USA (14 } \\
\text { states) }\end{array}$ \\
\hline $\begin{array}{c}\text { Total number } \\
\text { of patients }\end{array}$ & 138 & 333 & 193 & 145 & 44 & 1591 & 355 & 5700 & 178 \\
\hline $\begin{array}{l}\text { Age (median } \\
\text { years) }\end{array}$ & 56 & 50 & 64 & 47.5 & $>65$ & 63 & 79.5 & 63 & NR \\
\hline $\begin{array}{l}\text { Diabetic (\%) } \\
\text { within total } \\
\text { sample }\end{array}$ & 10.1 & 7.5 & 24.8 & 6.9 & 15.9 & 17 & 35.5 & 33.8 & 28.3 \\
\hline $\begin{array}{l}\text { Diabetic } \\
(\%) \text { within } \\
\text { ICU/severe } \\
\text { condition }\end{array}$ & 22.2 & 19.2 & 34.78 & 16.3 & 14.2 & NR & NR & NR & NR \\
\hline $\begin{array}{l}\text { Cardiovascu- } \\
\text { lar disease } \\
\text { within ICU/ } \\
\text { severe con- } \\
\text { dition }(\%)\end{array}$ & 16.7 & 30.8 & $27.1 * *$ & $60.5^{\$}$ & 35.29 & 21 & 35.5 & $\begin{array}{l}\text { Hypertension } \\
56.6 \\
\text { Coronary } \\
\text { artery dis- } \\
\text { ease } 11.1 \\
\text { Congestive } \\
\text { heart failure } \\
6.9\end{array}$ & 27.8 \\
\hline
\end{tabular}

$N R$ not reported

*Parameters of diabetic patients with Covid-19

\#Parameters of patients in ICU with sever Covid-19 symptoms

**Cardiovascular disease with diabetes

${ }^{\$}$ Patients presenting chest tightness

immune response starts acting on the $\beta$-cells, thereby developing autoimmunity [13]. Further, the fact that viral proteins tend to persist longer in human $\beta$-cells suggests their lower clearance rate of viral particles [14]. Type $1 \mathrm{DM}$ and autoimmunity emerging due to viral infections has been linked with genetic predisposition where function and regulation of genes involved in antiviral response, host immunity, $\beta$-cell structure and function affect the onset of the disease. The genetic variations favor virus induced type $1 \mathrm{DM}$ when genes involved in viral particle recognition, viral particle clearance, antiviral response and its downstream signaling have distinct DNA variants [15].

\section{Immune imbalance and inflammation from viral infection is directly related to severity and new onset in diabetic patients}

The $\beta$-cells infected by viruses lead to a cytotoxic immune response by presenting $\beta$-cell specific antigens to lymph nodes upon their death. This epitope spreading can induce an autoimmune response towards $\beta$-cells in the infected host [16]. In diabetic animal models, it has been confirmed that viral infections attract natural killer cells and $\mathrm{T}$ cells that produce inflammatory cytokines like interferon- $\gamma$, TNF- $\alpha$ and IL- $1 \beta$ leading to the destruction of $\beta$-cells [17]. Further, if viral antigens have homology to $\beta$-cell epitopes it can accelerate the incidence of type $1 \mathrm{DM}$ caused due to molecular mimicry [18]. Another mechanism that augments to $\beta$-cell death via the host immune system is bystander activation, where viral infections in the surrounding tissues produce inflammatory cytokines from their cell death. These cytokines would activate T cells specific to $\beta$-cells within pancreas or lymph nodes resulting in $\beta$-cell death $[15,19]$.

How SARS-CoV2 affects type 1 diabetic patients is yet to be confirmed. The presence of ACE-2 receptors on islet $\beta$-cells makes these cells a direct target for SARS-CoV2 spike protein binding, subsequent infection and ensuing deleterious effects. The cellular death due to viral infections causes inflammatory response. This altered cytokine/ chemokine profile around various tissue systems affects their characteristics and normal function, which is reflected in the clinical characteristics reported so far [5]. More importantly the fact that SARS-CoV leads to $\beta$-cell dysfunction causing acute diabetes [20], along with the above discussed case report of young patient developing new onset diabetes after SARS-CoV2 infection is sufficient to acknowledge the connection between SARS-CoV2 in diabetic disease pathogenesis and patient severity. 
Table 2 Clinical biochemical parameters of positive Covid-19 cases globally

\begin{tabular}{|c|c|c|c|c|c|c|}
\hline Report & [3] & {$[4]$} & {$[5]^{*}$} & {$[6]^{\#}$} & [7] & {$[10]$} \\
\hline $\begin{array}{l}\text { WBC } \\
\text { count, } \times 10^{9} / \mathrm{L} \\
\text { (ICU) } \\
\text { Normal range } \\
3.5-9.5\end{array}$ & $\begin{array}{c}6.6(3.6-9.8) \\
(\text { median })\end{array}$ & $\begin{array}{l}18.6 \% \leq \text { nor- } \\
\text { mal range \& } \\
0.3 \% \geq \text { normal } \\
\text { range }\end{array}$ & $\begin{array}{l}7.99(5.90 \text { to } \\
13.04)\end{array}$ & $6(4.44,7.40)$ & $\begin{array}{l}50 \% \text { leukopenia } \\
\quad(\text { white blood cell } \\
\text { count }<5000 \\
\left.\text { cells } / \mathrm{mm}^{3}\right)\end{array}$ & $7.0(5.2-9.5)$ \\
\hline $\begin{array}{l}\text { Neutrophil } \\
\text { count, } \times 109 / \mathrm{L} \\
1.8-6.3\end{array}$ & $4.6(2.6-7.9)$ & $\begin{array}{l}2.1 \% \leq \text { nor- } \\
\text { mal range \& } \\
0.4 \% \geq \text { normal } \\
\text { range }\end{array}$ & $\begin{array}{l}7.25 \text { (4.33 to } \\
11.81)\end{array}$ & $4.5(2.7,5.6)$ & NR & $5.3(3.7-7.7)$ \\
\hline $\begin{array}{l}\text { Lymphocyte } \\
\text { count, } \times 109 / \mathrm{L} \\
1.1-3.2\end{array}$ & $0.8(0.5-0.9)$ & $\begin{array}{l}10.8 \% \leq \text { nor- } \\
\text { mal range } \& \\
0.8 \% \geq \text { normal } \\
\text { range }\end{array}$ & $0.54(0.42$ to 0.93$)$ & $0.9(0.6,1.1)$ & $\begin{array}{l}\text { 88.63\% Lym- } \\
\text { phopenia } \\
\text { (lymphocyte } \\
\text { count }<1500 \\
\text { cells } / \mathrm{mm}^{3} \text { ) }\end{array}$ & $\begin{array}{l}0.88(0.6-1.2) \\
\text { Lympho- } \\
\text { cyte, }<1000 \times 109 / \mathrm{L} \\
3387(60 \%)\end{array}$ \\
\hline $\begin{array}{l}\text { Monocyte } \\
\text { count, } \times 109 / \mathrm{L} \\
0.1-0.6\end{array}$ & $0.4(0.3-0.5)$ & NR & NR & $0.4(0.3,0.5)$ & NR & NR \\
\hline $\begin{array}{l}\text { Platelet } \\
\text { count, } \times 109 / \mathrm{L} \\
125-350\end{array}$ & $142(119-202)$ & NR & $\begin{array}{l}161.0(126.5 \text { to } \\
232.5)\end{array}$ & $192(142,259)$ & $\begin{array}{l}43.18 \% \text { Thrombo- } \\
\text { cytopenia (plate- } \\
\text { lets }<150,000 / \\
\mathrm{mm}^{3} \text { ) }\end{array}$ & NR \\
\hline $\begin{array}{l}\text { D-dimer, mg/L } \\
0-0.5\end{array}$ & $\begin{array}{l}0.414(0.191- \\
1.324)\end{array}$ & NR & $2.6(1.0$ to 2.1$)$ & $0.32(0.21,0.49)$ & NR & $0.438(0.262-0.872)$ \\
\hline $\mathrm{C}$ reactive protein & NR & $\begin{array}{l}42.9 \% \geq \text { normal } \\
\text { range }\end{array}$ & NR & $\begin{array}{l}4.7 \mathrm{mg} / \mathrm{mL} \\
(1,26.78)\end{array}$ & $\begin{array}{l}18.18 \% \\
\text { CRP elevated } \\
(C R P>10 \mathrm{mg} / \\
\text { dL) }\end{array}$ & $\begin{array}{l}13.0(6.4-26.9) \\
\mathrm{mg} / \mathrm{dL}\end{array}$ \\
\hline
\end{tabular}

NA Not reported

*Parameters of Diabetic Patients with Covid-19

\#Parameters of Patients in ICU with sever Covid-19 symptoms

\section{SARS-CoV2 infection causes T cell imbalance and inflammation which is associated to increase disease severity in diabetic condition}

\section{COVID-19 and cytokine storm}

Earlier studies have relayed elevated levels of pro-inflammatory cytokines in patients infected with SARS-CoV and MERS-CoV. Similarly, with respect to SARS-CoV2, 41 COVID-19 confirmed cases were hospitalized, of which $20 \%$ had diabetes. The patients who were admitted had higher plasma concentration of cytokines and growth factors such as TNF- $\alpha$, PDGF, MCP-1, MIP-1A, MIP-1B, IP-10, IFN- $\gamma$, basic FGF, GCSF, GMCSF, VEGF, IL-1 $\beta$, IL-1RA, IL-7, IL-8, IL-9 and IL-10 than non-infected patients. Further, the plasma levels of following cytokines were higher in the patients admitted to intensive care units (ICU): TNF- $\alpha$, MCP-1, MIP-1A, IL-2, IL-7, IL-10, GCSF and IP-10 [21]. There is a marked difference in the cytokine profile between the COVID-19 infected patients in ICU compared to nonICU COVID-19 confirmed cases, which strongly indicates the connection between the cytokine storm and disease severity. Further, this cytokine storm would inevitably lead to multi-organ dysfunction due to hyper-inflammation, which in fact is observed in most of the critical COVID-19 cases globally [22].

\section{SARS-CoV2 infection causes T cell imbalance}

SARS-CoV2 infections have caused severe clinical conditions in many patients. In one such report, 286 COVID-19 patients out of 452 positive cases developed severe disease [23]. In these severe patients lymphocytopenia was observed based on immune cell phenotyping. It was observed that not only $\mathrm{CD}^{+} \mathrm{T}$ cell population decreased in these patients but also the ratio of naïve to memory $\mathrm{CD} 4^{+} \mathrm{T}$ cells increased. These reports also confirmed decrease in the number of $\mathrm{T}$ regulatory ( $\mathrm{T}$ regs) cell populations including induced $\mathrm{T}$ regs that restrain allergic response and naïve $\mathrm{T}$ regs which regulate autoimmunity. These alterations in the levels of immune cells caused an imbalance in functioning of the immune system. The reduced $\mathrm{T}$ reg population may further aid in enhancing the inflammatory damage. This along with increased neutrophil to lymphocyte ratio and higher 
levels of pro-inflammatory cytokines are related to hyperinflammation and infection, which is consistent with cases of critical patients in other COVID-19 reports [3, 23]. In SARS-CoV2 COVID-19 infected patients it is noticed that inflammatory cytokines like IFN- $\gamma$ and MCP-1 activate Th1 cells, which triggered specific immunity. However, on the other hand, these patients also express IL-4 and IL-10 which are secreted by $\mathrm{Th} 2$ cells, responsible for suppressing inflammatory responses [24]. Further, Th17 cells would get activated due to various cytokines such as IL1- $\beta$ and TNF- $\alpha$ present within the cytokine storm. Th17 themselves release IL-17, IL-21, IL-22 and GCSF. IL-17 is a pro-inflammatory cytokine which is broadly associated with autoimmunity and inflammatory diseases whereas GCSF promotes development of granulocytes and recruit neutrophils [25]. Another aspect of immune response relevant with COVID-19, SARSCoV2 viral infection is macrophage activation syndrome (MAS), which is characterized by the presence of elevated levels of IL-6, IL- $1 \beta$, IFN- $\gamma$ and TNF- $\alpha$ along with ferritin. This is highly associated with lung hyper-inflammation and ultimately development of acute respiratory distress syndrome (ARDS) [26].

\section{T cell imbalance and inflammation is also a characteristic clinical feature in both type 1 and 2 diabetes mellitus}

T cell imbalance and inflammation in type 1 diabetes mellitus The Th1/Th2 cells imbalance is greatly associated with diabetic condition. Th1 cells stimulated by IFN- $\gamma$ and IL-12 are essential in activation of macrophages and pathogen clearance; whereas Th2 cells get stimulated by IL-4, which regulate immune response towards allergies. Previously, in a rodent study it was reported that type $1 \mathrm{DM}$, which is an autoimmune disorder, observed an increase in stimulated Th1 cells in response to increased level of IFN- $\gamma$. IFN- $\gamma$ level is also elevated in viral induced type $1 \mathrm{DM}$ and is also observed in severe cases with COVID-19. However, in response to SARS-CoV2 infections there is no change in IL-4 levels resulting in an imbalance between Th1/Th2 cells. This disturbance in the balance results in increased inflammation and MAS. Further, IFN- $\gamma$ is implicated in upregulating MHC class 1 and II expressions and homing of Th1 cells towards pancreatic endocrine cells in non-obese diabetic (NOD) mice, thereby implicating itself in the progression of type 1 DM [21, 27]. Th17 cells that produce IL-17 have been previously confirmed to be present in abundance in type 1 diabetic human pancreas [28]. Further, elevated levels of IL- 6 and IL-1 $\beta$ as mentioned above in COVID-19 severe cases, can promote Th17 development which along with pro-inflammatory cytokines plausibly lead to islet inflammation causing $\beta$-cell death [29]. T cells that can express both IFN- $\gamma$ and IL-17 are called Th1/17 cells and have also been identified in type 1 diabetic patients [30]. This immune system imbalance may lead to $\beta$-cell dysfunction resulting in new onset diabetes in SARS-CoV2 infections.

T cell imbalance and inflammatory cytokines linking type 2 diabetes mellitus The elevated levels of IL-17 have also been detected in patients with type 2 diabetes, which have been linked to inflammation in adipose tissue. IL-17 regulates expression of TNF- $\alpha$ and NF-kB, which can lead to elevated pro-inflammatory cytokines expression causing chronic inflammatory responses at systemic level. This plays an essential role in development of insulin resistance in type 2 diabetic patients [31]. White adipose tissue is compromised for its secretory cytokine profile which involves several pro-inflammatory cytokines [32]. Further an imbalance in the immune system leading to changes in the macrophage phenotype has been observed with a shift from anti-inflammatory M2 type to pro-inflammatory M1-type [33]. There has been a direct molecular link that has previously proven the role of inflammatory cytokines in inducing insulin resistance in the peripheral tissue [34]. COVID-19, SARS-CoV2 viral infection induced cytokine storm along with the systemic immune cell and cytokine imbalance in diabetic patients would make their clinical state more aggravated and severe as identified in previous clinical reports and case studies. An insight into SARS-CoV2 infection and inflammation mediated severity in diabetes will be discussed in later sections.

\section{Immune cell imbalance leading to inflammation in diabetic state causes cardiomyopathy}

Patients with DM develop abnormality in myocardial structure and function, mainly in ventricles, leading to heart failure, even in absence of hypertension or any coronary artery or valve disease. Increase in glycemic and insulin index along with cardiac insulin resistance in diabetic patients lead to elevated levels of inflammation and oxidative stress in the cardiac tissue, which result in cardiac cell death and disassembly. All these factors cumulate towards hypertrophy, fibrosis and stiffness of the cardiac tissue leading towards dysfunction and heart failure. The initial phase of diabetic cardiomyopathy is characterized by development of cardiac diastolic dysfunction due to inflammation, oxidative stress and activation of RAAS pathway induced by glucotoxicity, cardiac insulin resistance and, metabolic and $\mathrm{Ca}^{2+}$ signaling dysregulation. The later phase includes progression towards clinical heart failure by worsening of diastolic dysfunction through LV hypertrophy and cardiac tissue disassembly directly affecting heart function.

Diabetic pathophysiology induces perturbations in the innate immune system thereby stimulating the pro-inflammatory cytokines which aid in the development and progression of cardiac myopathy [35]. Increased ROS, AGEs and 
activation of RAS pathway (discussed in the later section) in diabetic condition within the cardiac tissue can upregulate expression of transcription factors likes NF-KB, which can further regulate expression of pro-inflammatory cytokines and cell death. Activation of NF-KB in murine diabetic models has previously shown to increase ROS mediated endothelial and myocardial cell dysfunction and death in cardiac tissue. Further, due to increased ROS, macrophages accumulated within the cardiac tissue undergo pro-inflammatory M1 polarization, which further aids in promoting tissue inflammation by pro-inflammatory cytokines and growth factors that further stimulate fibrosis. Further, impaired macrophage function with respect to its phagocytosis and chemotactic activity has been previously observed in diabetic patients [36].

In diabetes, glucotoxicity and oxidative stress activate immune cells to create inflammatory niche in cardiac tissue. Presence of activated leucocytes with high production of ROS has been observed post MI in diabetic coronary microcirculation. Neutrophils in diabetic condition secrete pro-inflammatory cytokines, and form neutrophil extracellular traps which contribute towards sustained inflammatory response and prevent wound healing. CAD onset has been previously observed to be associated with increase in Th1, Th17 and Th22 lymphocytic subsets. Th1 and Th17 cells and their associated cytokines were upregulated, whereas Th2 population was suppressed in diabetic patients manifesting CAD. Further, a decline in Treg population that helps in inflammatory homeostasis and prevention of chronic inflammation is observed to have declined in diabetic patients associated with heart failures. Hence, in summary metabolic perturbations in diabetic condition leads to a systemic immune imbalance which results in activation of pro-inflammatory mechanisms resulting in cardiac inflammation thereby causing myocardial stiffness, disassembly, dysfunction and cell death. All of which gradually leads to heart failure in the chronic diabetic inflammatory state.

\section{COVID-19, ACE-2 receptors and their relation with diabetes and cardiovascular disorders}

\section{ACE-2 molecular machinery}

Classically renin-angiotensin system (RAS) entails the conversion of liver angiotensinogen to angiotensin-I (Ang-I) by renin in the kidney. Ang-I is further converted to angiotensin-II (Ang-II) by angiotensin-converting enzyme (ACE). Ang-II promotes electrolyte reabsorption from kidney and regulates vasoconstriction [37]. Ang-II can also induce ROS production by activating $\mathrm{NAD}(\mathrm{P}) \mathrm{H}$ oxidase [38]. In terms of promoting inflammation, Ang-II and RAS signaling stimulate the production of various pro-inflammatory cytokines and chemoattractant like MCP-1. It also triggers an increase in vascular permeability by elevating VEGF secretion to increase infiltrating immune cells [39]. ACE-2 is monocarboxy-peptidase, zinc metalloprotease enzyme with a $42 \%$ homology with ACE. The membrane bound ACE- 2 is cleaved at its ectodomain by ADAM-17 to generate its soluble form. ACE-2 converts Ang-II to Ang-(1-7). Ang-(1-7) binds to Mas receptor, which activates the release of bradykinin, nitric oxide, prostaglandin and inhibits the release of norepinephrine, which results in vasodilation [40, 41]. The earlier reports confirm that ACE-2 presents itself as a receptor for SARS-CoV and several recent reports on COVID-19 pandemic now suggest that ACE-2 is the receptor for SARS-CoV-2 COVID-19 as well [42, 43] (Fig. 1).

\section{Mechanism of ACE-2 receptor in diabetic complications}

The RAS system has been reported to be in a hyperactive state in the diabetic condition [40]. The inhibition of RAS has shown amelioration in diabetic condition by increasing insulin sensitivity and glucose uptake in both adipose and muscle tissue. In liver and pancreas, it has been reported to prevent fibrosis and oxidative damage along with increase in insulin release from the pancreas. ACE- 2 counter the RAS pathway and abates the progression of several pathological processes in various tissues in the diabetic condition [40]. In diabetic condition, elevated levels of ACE were observed in serum, heart, lung, and liver, while ACE-2 was significantly increased in serum, liver and pancreas [44]. Further, diabetic nephropathy follows deletion of ACE-2 gene in type

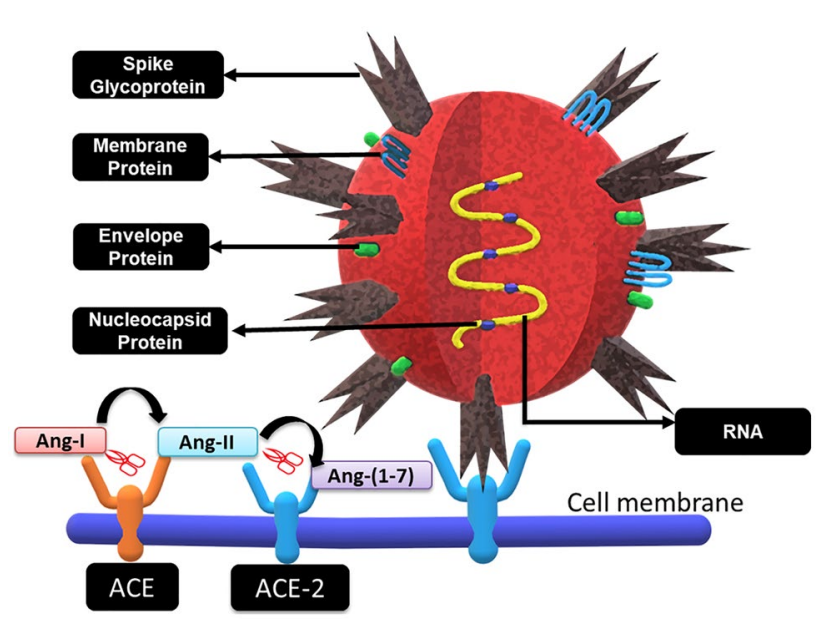

Fig. 1 SARS-CoV2 Covid-19 structure and docking with ACE-2 receptor. ACE and ACE-2 receptors are transmembrane proteins. ACE converts Ang-I to Ang-II, which is further cleaved into Ang(1-7) by ACE-2. The SARS-COV-2 Covid-19 viral RNA codes for 4 vital structural proteins viz. transmembrane Spike glycoprotein (S), membrane (M), envelope (E) and Nucleocapsid protein (N) 
1 diabetic mice [45]. Also, Mas knockout mice develop insulin resistance and faulty glucose uptake thereby associating the ACE-2/Ang-(1-7)/Mas axis with type 2 DM [46]. Ang(1-7) in skeletal muscles could enhance insulin sensitivity and insulin dependent glucose uptake thereby ameliorating insulin resistance [47].

\section{Renin-angiotensin system in diabetes induces cardiovascular disorders}

RAS has a profound effect on the development of cardiovascular complications in diabetic state. Hyperglycemia induced increase in Ang-II levels has been previously observed in cardiac tissue. Ang-II has an adverse effect on insulin receptor and downstream insulin signaling, thereby aiding the insulin resistance condition in the cardiac tissue [48]. Further, Ang-II via AT-1 receptor induced a signaling cascade involving JAK-STAT pathway, MAP kinase pathway and inositol phosphate recruiting NF-AT3 to promote proliferation of cardiac fibroblasts. Ang-II via AT-1 also activates p53 which triggers apoptosis in these cells causing cardiac fibrosis [49]. In response to oxidative stress and inflammatory conditions in the diabetic condition, NF-KB is activated in the cardiac tissue which further regulates and enhances the pro-inflammatory mediated tissue damage. It is reported that Ang-II induces the expression of NF-KB through TLR-4/JNK signaling in the cardiac tissue, which further leads to endothelial dysfunction, vascular remodeling and stiffness [50]. Patients with diabetic condition are often treated with ACE inhibitors and Ang-II type 1 receptor blockers (ARBs) along with other antidiabetics like thiazolidinedoines which all upregulate the expression of ACE-2. Similarly, patients with hypertension are also treated with ACE inhibitors and ARBs. This condition is uniquely poised for developing a more severe and alarming SARS-CoV2 infection among such patients [51].

\section{ACE-2 and beta cell survival in diabetic patients}

The islets of Langerhans makes up the endocrine part $(1-2 \%)$ of the whole pancreas, and $70-90 \%$ of islet is comprised of insulin producing $\beta$-cells. The acinar cells along with endothelial cells which make up the microvascular part that supply blood, together makes up $98 \%$ of the exocrine pancreatic tissue [52]. The $\beta$-cells are known to have low levels of antioxidant enzymes when compared to other types of cells present in the endocrine pancreas, which makes them specifically vulnerable to oxidative stress leading to cell death [53]. The ACE-2 receptors are expressed in the exocrine (acinar) and endocrine (islets) system of the pancreas [54]. It is reported that ACE-2 knockout mice demonstrate decreased capacity of insulin secretion in response to glucose [55]. Further, ACE-2 gene therapy in 8-week db/ db mice improved blood glucose, increased islet function, $\beta$-cell proliferation and survival. However, it only improved glucose homeostasis with no effect on $\beta$-cells when mice were given gene therapy after 16 weeks [56]. It was reported that disruption in glycemic homeostasis with pancreatic $\beta$-cell dysfunction is caused due to decreased ACE-2 levels. Therefore, lowered ACE-2 levels would elevate serum Ang-II which would increase $\beta$-cell Ang-II receptors and augment the RAS pathway, thereby increasing oxidative stress in $\beta$-cells. However, ACE- 2 gene therapy ameliorated the above condition thereby affecting $\beta$-cell survival. In this study, the restoration of ACE-2 enzyme expression and activity was associated with decreased $\beta$-cell oxidative stress, increased glucose stimulated insulin secretion (GSIS) and improved overall $\beta$-cell function [57]. In a recent study, deficiency of ACE- 2 caused negative impact on $\beta$-cell mass and proliferation in mice [58]. It was observed that ACE-2Ang (1-7)-mas axis decreases pro-inflammatory cytokine levels including interleukin-6 (IL-6) and interleukin-8 (IL-8) and increases anti-inflammatory cytokines including interleukin-10 (IL-10) levels. This was associated with increased expression of P13K/AKT pathway and eNOS in the exocrine pancreas as well as improvement in pancreatic function [59]. In another study, it was concluded that ACE-2-Ang-(1-7)mas axis inhibits pancreatitis by downregulating pro-inflammatory cytokines such as IL-6, IL- 8 and TNF- $\alpha$ and abating p38MAPK/NF-KB pathway [60]. The above axis activates the Akt/NOS/NO pathway in endothelial cells, which is essential for pancreatic homeostasis, thereby improving $\beta$-cell survival and function [61]. However, presence of ACE- 2 on $\beta$-cells and other tissues would make these tissue systems more susceptible and impacted during a SARSCoV-2 infection (Fig. 2).

\section{COVID-19, ACE receptors and their relation to severity of cardiovascular condition in diabetes patients}

\section{SARS-CoV2 structure proteins and ACE-2 receptor}

The SARS-CoV-2 COVID-19 viral RNA codes for 4 vital structural proteins viz. transmembrane spike glycoprotein (S), membrane (M), envelope (E) and nucleocapsid protein (N) (Fig. 1). The S protein is a homotrimer which allows the virus to anchor to the host cellular surface and fuse with its membrane. It has two domains, $\mathrm{S} 1$ which has a receptor binding domain (RBD) and $\mathrm{S} 2$ which assists the viral and membrane fusion. Further, a cellular serine protease, i.e. TMPRSS2 is required for priming and cleaving the S protein at S2' site of S1/S2, followed by S2 mediated viral fusion [62]. As described in the above sections, in diabetic condition there is elevation in the expression of 

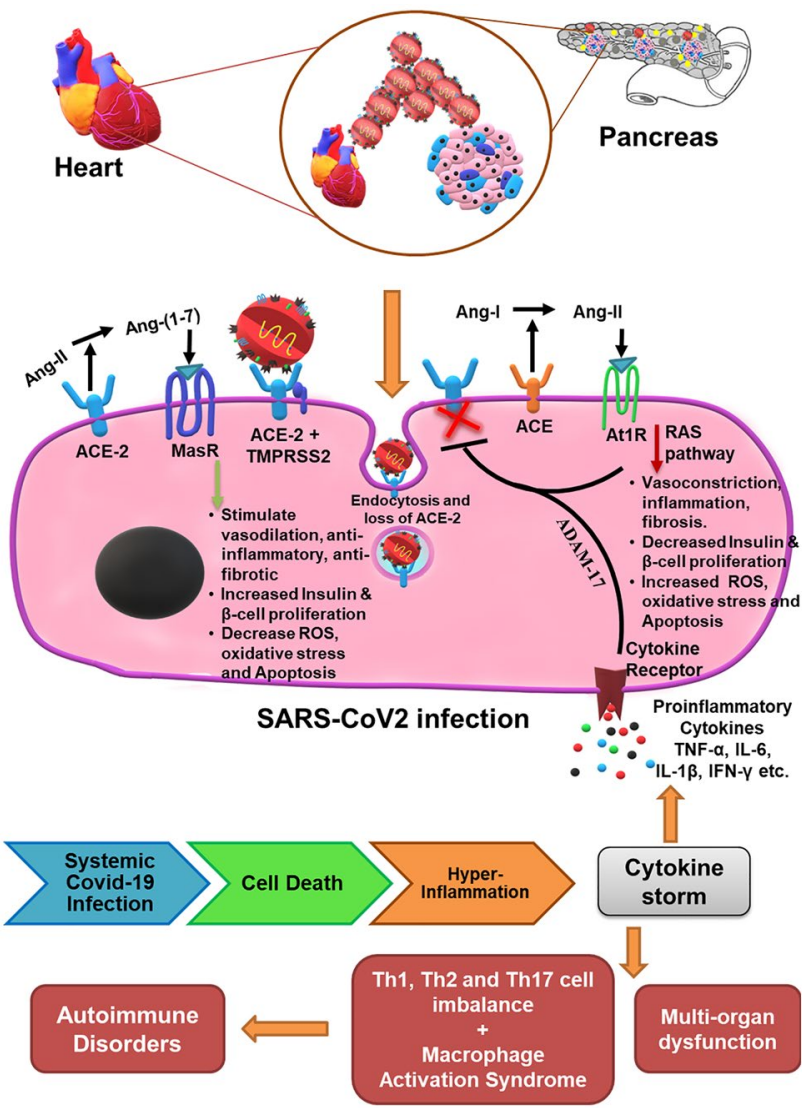

Fig. 2 Pathogenesis of Covid-19 in heart and $\beta$-cells through ACE-2 receptor in diabetic patients. ACE receptor converts Ang-I to Ang-II, which has detrimental effects through the RAS pathway, thereby increasing systemic oxidative stress and apoptosis leading to decrease in proliferation and insulin secretion by $\beta$-cells along with an increase in the risk of cardiovascular complications. Whereas, ACE-2 receptor has protective effect on $\beta$-cells by converting the Ang-II to Ang-(1-7) which through Mas receptor stimulates vasodilatory, anti-inflammatory and anti-fibrotic signaling and decreases oxidative stress, provides antiviral defences, increases $\beta$-cell proliferation and insulin secretion. However, Covid-19 infection reduces ACE-2 receptors on the cell surface by directly binding ACE- 2 and its endocytosis, which releases suppression of RAS and in turn further reduces ACE- 2 expression. Further, the cytokine storm caused due to the hyper-inflammation of the Covid-19 infection release the pro-inflammatory cytokines that activate ADAM-17 and cleave the ACE-2 receptors from the membrane surface. The cytokine storm along with the immune cell imbalance not only adversely affects the cardiac tissue and $\beta$-cells but it will cause organ dysfunction at systemic level

ACE-2 receptor at a multi organ level, which would possibly lead to an increase in the cellular tropism involved with SARS-CoV-2. Further, ACE-2 counters the RAAS pathway as discussed earlier in cardiovascular disorders. The internalization of ACE-2-virus complex decreases the ACE-2 receptors on the cell surface along with inhibition of ACE-2 by unknown viral particles [63], thereby rendering the ACE-2/Ang-(1-7)/mas axis ineffective making the cardiovascular and diabetic condition under the influence of SARS-CoV-2 COVID-19 more severe (Fig. 1).

\section{Role of ADAM-17 in relation to COVID-19, diabetes and its cardiovascular complications}

TNF- $\alpha$ converting enzyme (TACE) known as ADAM-17 is a $\mathrm{Zn}$ metalloprotease of the adamalysin subfamily. It activates TNF- $\alpha$, which is responsible for chronic inflammation. ADAM-17 is known to activate other cytokines and receptors. ACE- 2 being one such receptor is cleaved by ADAM-17 leading to enhanced activation of RAS pathways that leads to oxidative stress and subsequent inflammation. RAS activation involves phosphorylation of ADAM-17 that catalyzes the shedding of ACE-2 from the cell membrane thereby creating a positive feedback loop. Increase in ADAM-17 expression has been reported in cardiac tissue under the influence of ectopic Ang-II [64], which is followed by significant reduction in membrane bound myocardial ACE2 and rise in plasma ACE2 levels. Wang et al., have previously shown that silencing of ADAM-17 prevented progression of cardiac hypertrophy and fibrosis in presence of Ang-II [65]. During COVID-19, SARS-CoV2 viral infection, viral binding to ACE-2 receptors decreases the overall receptor expression that leads to abatement of ACE-2 mediated protective response and activation of ADAM-17 by activation of RAS pathway. In diabetic condition it was observed that ADAM-17, that causes shedding of ACE-2 does not deplete it from the surface of islets within pancreas, which during COVID-19, SARS-CoV2 viral infection serves as docks for the viral entry followed by inflammatory responses as described above [66]. In previous studies with SARS-CoV, it has been observed that viral entry was severely hampered on downregulating the expression of ADAM-17. Hence, it is possible that for the SARS-CoV-2 infection, inhibition of ADAM-17 may play a vital role in restricting viral entry and retaining ACE-2 function [43].

\section{Impaired $\beta$-cell and cardiac function due to glycated hemoglobin $\left(\mathrm{HbA}_{1 \mathrm{C}}\right)$ levels in SARS-CoV2 infections}

Clinical description of COVID-19 patients throughout the world has shown higher than normal levels of glycated hemoglobin. Interestingly, an inverse relationship between glycated hemoglobin levels and $\beta$-cell function has been well established. Increase in $\mathrm{HbA}_{1 \mathrm{C}}$ levels correspond to a significant decrease in insulin sensitivity and $\beta$-cell function as shown in Mexican American subjects [67]. Thereafter, in more than 10,000 subjects, a direct correlation was established between increase in insulin resistance and loss of $\beta$-cell function with an increase in $\mathrm{HbA}_{1 \mathrm{C}}$ levels independent of gender, age, or body mass index [68]. This has been 
further validated in non-diabetic off springs of type 2 diabetic individuals where in response to elevated $\mathrm{HbA}_{1 \mathrm{C}}$ levels acute loss of insulin sensitivity followed with decreased $\beta$-cell function was observed [69]. Previous clinical studies have shown a direct link between reduction in $\mathrm{HbA}_{1 \mathrm{C}}$ levels corresponding to a reduction in heart failure risk. It was seen that a $1 \%$ reduction in $\mathrm{HbA}_{1 \mathrm{C}}$ reduces $16 \%$ risk of manifesting heart failures [70]. Another study established that glycated hemoglobin levels above $6 \%$ have a direct implication with an increased risk of developing cardiovascular complications [71]. Further, with respect to COVID-19 pandemic, elevated levels of $\mathrm{HbA}_{1 \mathrm{C}}$ has been clinically associated with inflammation, thrombosis and death rate suggesting that patient severity was directly associated with elevated $\mathrm{HbA}_{1 \mathrm{C}}$ levels [72]. Hence, an existing robust correlation can be drawn between the disease pathogenesis and its severity presented for heart diseases in diabetic or hyperglycemic patients suffering from SARS-CoV2 infections.

\section{SARS-CoV2, imbalance in ACE-2/RAS signaling, insulin sensitivity and hyperglycemia leads to $\beta$-cell and cardiac tissue dysfunction-a vicious circle}

The relationship between diabetes and SARS-CoV2 infection appears to be bi-directionally correlated. It seems that the infected state becomes more severe in patients with preexisting diabetes whereas there is also a possibility of new onset diabetes post SARS-CoV2 infection [73]. The cause for either is unclear. However, pathogenic load causing systemic inflammation has been directly linked to insulin resistance and development of type 2 DM [74]. Triglycerideglucose (TyG) index (marker for insulin resistance) is associated with metabolic disorder was observed to be accompanied with critical patients infected with SARS-CoV2 [75]. ACE-2/Ang-(1-7)/mas pathway is rendered inactive due to internalization of ACE-2 receptors by SARS-CoV2, which activates the Ang-II mediated RAS pathway. Further, progression of SARS-CoV2 triggers RAS pathway to stimulate oxidative stress and inflammation [43]. Moreover, Ang-II has been strongly implicated in promoting insulin resistance by desensitizing the insulin signaling pathway in the peripheral tissue [76]. RAS further aids in the development of insulin resistance in response to pro-inflammatory stimulation [76]. Insulin resistance can increase free fatty acids in circulation from adipocytes which trigger a cascade of events to decrease overall HDL and increase LDL which are both risk factors for cardiovascular diseases [77]. Activation of RAS pathway also triggers elevation in blood pressure along with vasoconstriction and cardiac contractility [78]. Hyperglycemia in SARS-CoV2 infected patients has been directly correlated as an independent risk factor associated with increased severity and mortality [79-81]. Classically it is well understood that systemic hyperglycemic condition leads to glucotoxicity, $\beta$-cell dysfunction and diabetic cardiomyopathy $[82,83]$. It is observed that hyperglycemia upregulates expression of angiotensinogen, ACE and AngII [84]. Alternatively, ACE-2 receptors in diabetic condition were upregulated in serum, liver and pancreas in NOD mice [44]. ACE-2 receptor deletion in NOD mice severely affected glucose homeostasis and decreased $\beta$-cell function [85]. $\beta$-cell dysfunction and their dedifferentiation was observed in a high fat mice model in response to ACE-2 knockout, which gets ameliorated by stimulation of ACE-2/ Ang-(1-7)/mas signaling [86]. Susceptibility of $\beta$-cells to SARS infection have been previously reported which led to $\beta$-cell death followed by acute diabetes [20]. All this indicates that high glucose could lead to an increase in ACE-2 expression in the insulin producing $\beta$-cells which then may get adversely affected by the SARS-CoV2. To validate this claim, a recent study has shown that with increased inflammatory stress condition, the expression of ACE- 2 receptors on $\beta$-cells in human pancreas is preferentially and significantly upregulated making these cells more susceptible and targeted during SRAS-CoV2 infection [87]. Further, we also know that SARS-CoV2 viral spike proteins bind to ACE-2 receptors and both the virus and the receptors are heavily glycosylated [88, 89]. This glycosylation not only facilitates viral selectivity and entry into the cells but also acts as a shield against antibody recognition [90]. It is possible that systemic high glucose may lead to higher glycosylation rates of these molecules thereby worsening the SARS-CoV2 infection state [91]. These evidences indicate that there is a vicious cycle at play where SARS-CoV2 targets the ACE-2 receptors on peripheral tissues increasing insulin resistance and hyperglycemia, which would in turn affect $\beta$-cell burn out along with increasing hypertension and increased risk of cardiovascular complications. $\beta$-cells by themselves expressing ACE-2 would fall prey to the virus. Further, hyperglycemic condition would increase viral infection in peripheral tissue and $\beta$-cells along with activation of RAS pathway would facilitate more adverse patient condition. This would explain the increased deteriorating patient heart condition in existing diabetic patients contracting SARS-CoV2 in COVID-19 patients (Fig. 3).

\section{SARS-CoV-2 hypercoagulability in relation to diabetic cardiomyopathy}

There is an alarming rate of mortality in diabetic patients due to blood clotting and $2 / 3^{\text {rd }}$ of these patients succumb to MI [92]. Endothelial dysfunction is a characteristic feature in diabetic cardiomyopathy which aids in manifestation of thrombotic events. Since endothelial von Willebrand factor (vWF) expression is increased during exposure to angiotensin II-induced oxidative stress [93], it is conceivable that platelets are highly activated in diabetic condition which 
Fig. 3 SARS-CoV2, imbalance in ACE-2/RAS signaling, insulin sensitivity and hyperglycemia leading to cardiac and $\beta$-cell dysfunction-a vicious circle. A cycle at play where SARS-CoV2 targets the ACE-2 receptors on peripheral tissues increasing insulin resistance and hyperglycemia, which would in turn affect $\beta$-cell burn out and increases the risk of cardiovascular complications. Cardiac tissue and $\beta$-cells by themselves expressing ACE- 2 would fall prey to the virus. Further hyperglycemia can upregulate the ACE-2 receptor expression there by increasing the systemic vulnerability towards SARS-

CoV2 attack

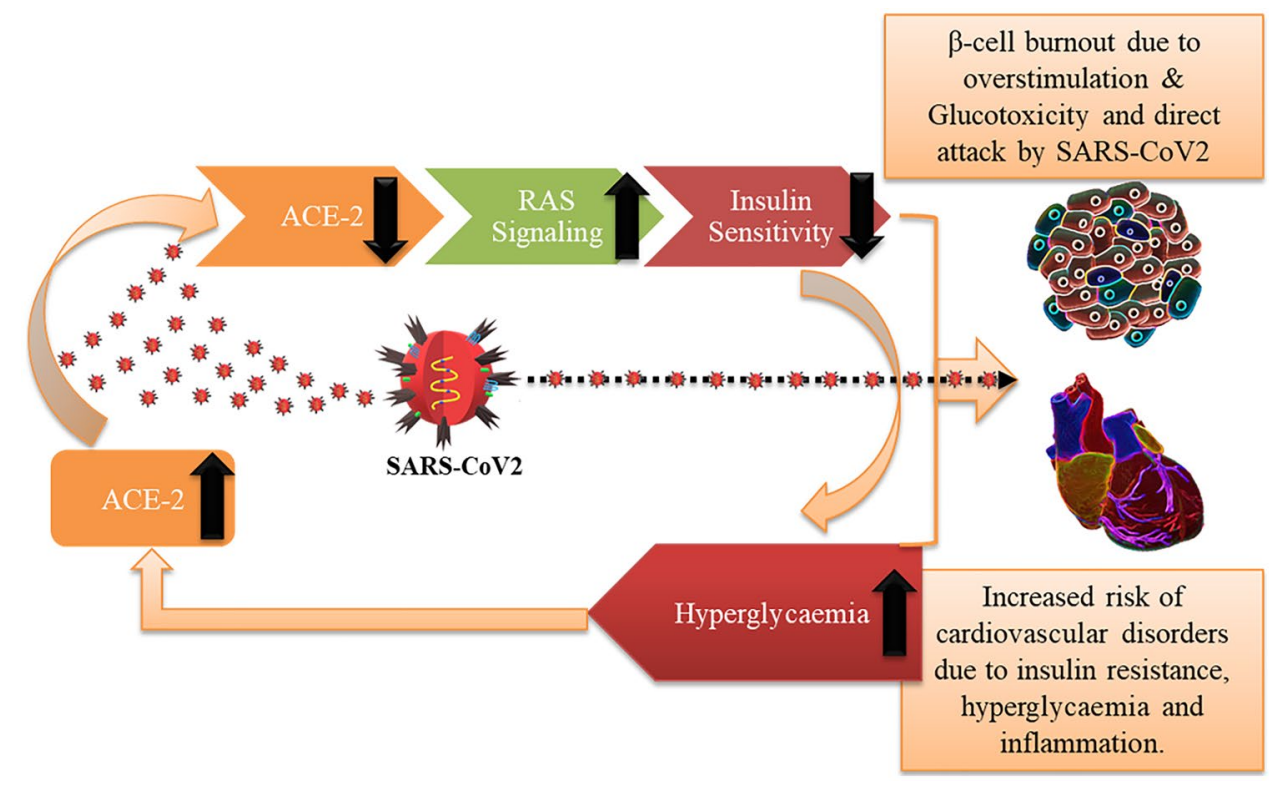

allows increased platelet aggregation and coagulation products. Diabetic patients with insulin resistance, even complicated by cardiovascular diseases, also show elevated levels of clotting factors like fibrinogen, factor VII \& vWF [94] and reduced anticoagulating mechanisms like the fibrinolytic system due to abnormal clotting and elevated levels of PAI-1 [77]. Further, an emerging opinion among COVID-19 related research and clinical community is the presence of elevated D-dimer levels in COVID-19 patients connecting to venous thromboembolism and presence of pulmonary emboli in many of the COVID-19 patients [95] (Table 2). This is supported by the fact that activation of coagulation during infection leads to an intense inflammatory response causing multi organ failure. Thrombin creates clots by converting fibrinogen to fibrin and could promote inflammatory response through proteinase-activated receptors (PARs) especially PAR-1. The inhibitors that can suppress this response could be tested and developed as a new therapeutic line for the COVID-19 patients [96].

\section{Influence of other comorbidities on SARS-CoV2 infected patients}

Disease severity in COVID-19 patients is not just a function of their diabetic state but other comorbidities also have significant influence on patient condition. Hypertension, obesity, cardiovascular and renal disorders are some of the underlying conditions that can influence both severity and survival of COVID-19 patients. Mortality during COVID-19 has been directly linked to underlined disease where more number of underlying diseases increased the mortality rate from $0.8 \%$ with no disease, to $48.5 \%$ with 3 or more underlying disorders [9]. Obesity has also been associated with a sixfold increase in disease severity among the SARS-CoV2 affected individuals [97]. An increased prevalence of obesity was observed in critically ill COVID-19 patients admitted to ICU [98]. Further, since both diabetes and obesity are characterized with altered cytokine profiles leading to chronic systemic inflammation, they may cause a synergistic effect on enhancing disease severity in COVID-19 patients [99]. In a retrospective study from the Lombardy region in Italy, mortality rate was found to be significantly higher in patients with hypertension that were admitted to ICU, where fewer patients with hypertension were discharged from ICU [8]. 69.4\% mortality was observed accompanied with hypertension and $40.5 \%$ with diabetes in a report presenting clinical outcomes from New York City [10]. Similarly, mortality rate of $53.8 \%$ was observed in non-survivors having both hypertension and diabetes together. $28.2 \%$ non-survivors had cardiovascular disorders with diabetic condition [5]. Cardiovascular and metabolic disorders have been observed to accompany increased severity in COVID-19 patients [100]. Proteinurea was observed in $43.9 \%$ of COVID19 patients when hospitalized and 5.1\% with acute kidney injury. A high prevalence of elevated serum creatinine, blood urea nitrogen and below normal estimated glomerular filtration rate was observed [101]. Also, acute kidney injury was observed among $80.3 \%$ non-survivors with diabetic condition [5]. Hence, presence of other comorbidities along with diabetes can be correlated to an increased severity and mortality rate among COVID-19 patients. 


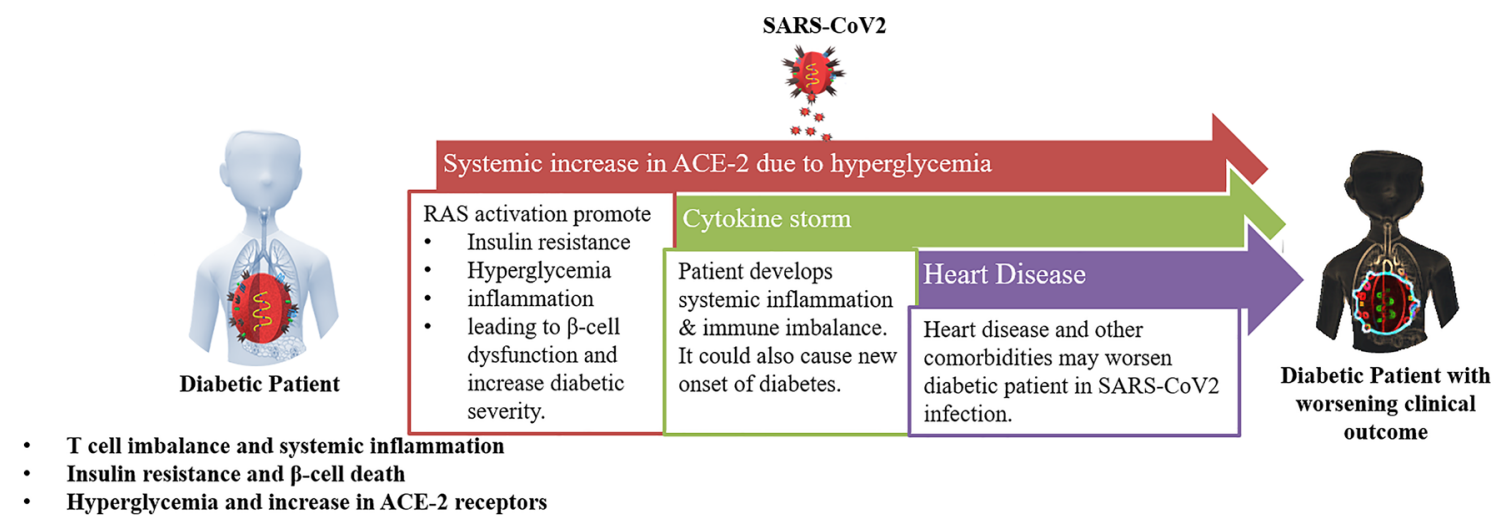

Fig. 4 Graphical summary explaining the effect of diabetes and heart disease towards severity of clinical condition during SARS-COV2 infections

\section{In conclusion, there is a high risk of developing and worsening cardiovascular complications in diabetic patients with SARS-CoV2 infection}

In conclusion, we believe that COVID-19, SARS-CoV2 viral infection causes a multi organ distress disease by creating an imbalance between the host cellular and cytokine immune system resulting in a hyper-inflammatory cytokine storm affecting systemic homoeostasis. COVID-19, SARSCoV2 viral infections in diabetic patients who already have compromised and imbalance immunity lead to further deterioration of their overall condition making it more severe. Further, $\beta$-cells are classically susceptible to oxidative stress experience an increase in inflammation and ACE-2 receptor depletion during COVID-19, SARS-CoV2 viral infections, which possibly negatively impacts $\beta$-cell function and survival, thereby increasing severity of the disease. Disease severity in COVID-19 patients is not just a function of their diabetic state but other comorbidities also have significant influence on patient condition. Mortality during COVID-19 has been directly linked to underlying disorders where the mortality rate increases from $0.8 \%$ with no disease to $48.5 \%$ with 3 or more underlying disorders [9]. Cardiovascular disease is one of the underlying conditions that can influence both severity and outcome of older COVID-19 patients [102, 103]. In the previous sections we have discussed prevalence of diabetes in COVID-19 patients; however, the risk of heart failure has also been observed similarly [104]. Sars-CoV2 can directly affect cardiac tissue leading to inflammatory stress response and cardiac dysfunction [105]. However, cardiovascular and metabolic disorders have been observed to accompany increased severity in COVID-19 patients and there is multi-fold increase in cardiovascular disease in diabetic SARS-CoV2 infected patients [100] (Fig. 4). Severity of diabetic patients with SARS-CoV2 infection could lead to pulmonary embolism due to increased D-dimer levels leading to hypercoagulation, causing hypoxia and heart failure [106]. Further, we have previously discussed the role of hyperglycemia in increasing the expression of ACE-2 receptors on cell surface, which would than enhance the susceptibility of cardiac cells to SARS-CoV2 onslaught. SARS$\mathrm{CoV} 2$ binding to ACE-2 activates RAS pathway which in turn triggers oxidative stress and inflammatory pathways leading to hypertension, myocardial arrhythmia and injury in cardiac tissue [107].

Author contributions Conception (AS \& SD), Designing (AS \& SD), Literature survey (AS \& NS), Writing and Final Approval of Manuscript (AS, CRG, NS, VL and SD).

Funding This work is funded by Canadian Institutes of Health Research (CIHR) (Grant No. PJT156148).

Data availability All the data related to this review article are available in this article and respective cited literature.

Code availability Not Applicable.

\section{Declarations}

Conflict of interest Authors report no financial or non-financial conflict of interests.

Ethical approval and consent to participate This is an original review article where no ethical approval or informed consent was applicable.

Consent for publication All authors have read and agreed to the publication of this manuscript.

\section{References}

1. Karamanou M, Protogerou A, Tsoucalas G, Androutsos G, Poulakou-Rebelakou E (2016) Milestones in the history of diabetes 
mellitus: the main contributors. World J Diabetes 7:1-7. https:// doi.org/10.4239/wjd.v7.i1.1

2. Saeedi P, Petersohn I, Salpea P, Malanda B, Karuranga S, Unwin N, Colagiuri S, Guariguata L, Motala AA, Ogurtsova K (2019) Global and regional diabetes prevalence estimates for 2019 and projections for 2030 and 2045: results from the International Diabetes Federation Diabetes Atlas. Diab. Res. Clin. Pract. 157:107843

3. Wang D, Hu B, Hu C, Zhu F, Liu X, Zhang J, Wang B, Xiang H, Cheng Z, Xiong Y, Zhao Y, Li Y, Wang X, Peng Z (2020) Clinical characteristics of 138 hospitalized patients with 2019 novel coronavirus-infected pneumonia in Wuhan, China. JAMA. https://doi.org/10.1001/jama.2020.1585

4. Yu X, Sun X, Cui P, Pan H, Lin S, Han R, Jiang C, Fang Q, Kong D, Zhu Y, Zheng Y, Gong X, Xiao W, Mao S, Jin B, Wu H, Fu C (2020) Epidemiological and clinical characteristics of 333 confirmed cases with coronavirus disease 2019 in Shanghai, China. Transbound Emerg Dis. https://doi.org/10.1111/tbed.13604

5. Yan Y, Yang Y, Wang F, Ren H, Zhang S, Shi X, Yu X, Dong K (2020) Clinical characteristics and outcomes of patients with severe covid-19 with diabetes. BMJ Open Diabetes Res Care. https://doi.org/10.1136/bmjdrc-2020-001343

6. Chen Q, Zheng Z, Zhang C, Zhang X, Wu H, Wang J, Wang $S$, Zheng C (2020) Clinical characteristics of 145 patients with corona virus disease 2019 (COVID-19) in Taizhou, Zhejiang, China. Infection. https://doi.org/10.1007/s15010-020-01432-5

7. Colaneri M, Sacchi P, Zuccaro V, Biscarini S, Sachs M, Roda S, Pieri TC, Valsecchi P, Piralla A, Seminari E, Di Matteo A, Novati S, Maiocchi L, Pagnucco L, Tirani M, Baldanti F, Mojoli F, Perlini S, Bruno R, TaskF TCISMP (2020) Clinical characteristics of coronavirus disease (COVID-19) early findings from a teaching hospital in Pavia, North Italy, 21 to 28 February 2020. Euro Surveill. https://doi.org/10.2807/1560-7917.ES.2020.25.16. 2000460

8. Grasselli G, Zangrillo A, Zanella A, Antonelli M, Cabrini L, Castelli A, Cereda D, Coluccello A, Foti G, Fumagalli R, Iotti G, Latronico N, Lorini L, Merler S, Natalini G, Piatti A, Ranieri MV, Scandroglio AM, Storti E, Cecconi M, Pesenti A, Network C-LI, Nailescu A, Corona A, Zangrillo A, Protti A, Albertin A, Forastieri Molinari A, Lombardo A, Pezzi A, Benini A, Scandroglio AM, Malara A, Castelli A, Coluccello A, Micucci A, Pesenti A, Sala A, Alborghetti A, Antonini B, Capra C, Troiano C, Roscitano C, Radrizzani D, Chiumello D, Coppini D, Guzzon D, Costantini E, Malpetti E, Zoia E, Catena E, Agosteo E, Barbara E, Beretta E, Boselli E, Storti E, Harizay F, Della Mura F, Lorini FL, Donato Sigurta F, Marino F, Mojoli F, Rasulo F, Grasselli G, Casella G, De Filippi G, Castelli G, Aldegheri G, Gallioli G, Lotti G, Albano G, Landoni G, Marino G, Vitale G, Battista Perego G, Evasi G, Citerio G, Foti G, Natalini G, Merli G, Sforzini I, Bianciardi L, Carnevale L, Grazioli L, Cabrini L, Guatteri L, Salvi L, Dei Poli M, Galletti M, Gemma M, Ranucci M, Riccio M, Borelli M, Zambon M, Subert M, Cecconi M, Mazzoni MG, Raimondi M, Panigada M, Belliato M, Bronzini N, Latronico N, Petrucci N, Belgiorno N, Tagliabue P, Cortellazzi P, Gnesin P, Grosso P, Gritti P, Perazzo P, Severgnini P, Ruggeri P, Sebastiano P, Covello RD, Fernandez-Olmos R, Fumagalli R, Keim R, Rona R, Valsecchi R, Cattaneo S, Colombo S, Cirri S, Bonazzi S, Greco S, Muttini S, Langer T, Alaimo V, Viola U (2020) Baseline characteristics and outcomes of 1591 patients infected with SARS-CoV-2 admitted to ICUs of the Lombardy Region, Italy. JAMA. https://doi.org/10.1001/jama.2020.5394

9. Onder G, Rezza G, Brusaferro S (2020) Case-fatality rate and characteristics of patients dying in relation to COVID-19 in Italy. JAMA. https://doi.org/10.1001/jama.2020.4683

10. Richardson S, Hirsch JS, Narasimhan M, Crawford JM, McGinn T, Davidson KW, the Northwell C-RC, Barnaby DP, Becker LB,
Chelico JD, Cohen SL, Cookingham J, Coppa K, Diefenbach MA, Dominello AJ, Duer-Hefele J, Falzon L, Gitlin J, Hajizadeh N, Harvin TG, Hirschwerk DA, Kim EJ, Kozel ZM, Marrast LM, Mogavero JN, Osorio GA, Qiu M and Zanos TP, (2020) Presenting characteristics, comorbidities, and outcomes among 5700 patients hospitalized with COVID-19 in the New York City area. JAMA. https://doi.org/10.1001/jama.2020.6775

11. Garg S, Kim L, Whitaker M, O'Halloran A, Cummings C, Holstein R, Prill M, Chai SJ, Kirley PD, Alden NB, Kawasaki B, Yousey-Hindes K, Niccolai L, Anderson EJ, Openo KP, Weigel A, Monroe ML, Ryan P, Henderson J, Kim S, Como-Sabetti K, Lynfield R, Sosin D, Torres S, Muse A, Bennett NM, Billing L, Sutton M, West N, Schaffner W, Talbot HK, Aquino C, George A, Budd A, Brammer L, Langley G, Hall AJ, Fry A (2020) Hospitalization rates and characteristics of patients hospitalized with laboratory-confirmed coronavirus disease 2019 - COVID-NET, 14 states, March 1-30, 2020. MMWR Morb Mortal Wkly Rep 69:458-464. https://doi.org/10.15585/mmwr.mm6915e3

12. Galleri L, Sebastiani G, Vendrame F, Grieco FA, Spagnuolo I, Dotta F (2013) Viral infections and diabetes. Springer, Diabetes, pp 252-271

13. Marroqui L, Lopes M, dos Santos RS, Grieco FA, Roivainen M, Richardson SJ, Morgan NG, Eizirik DL (2015) Differential cell autonomous responses determine the outcome of coxsackievirus infections in murine pancreatic $\alpha$ and $\beta$ cells. Elife 4:e0990

14. Krogvold L, Edwin B, Buanes T, Frisk G, Skog O, Anagandula M, Korsgren O, Undlien D, Eike MC, Richardson SJ (2015) Detection of a low-grade enteroviral infection in the islets of langerhans of living patients newly diagnosed with type 1 diabetes. Diabetes 64:1682-1687

15. De Beeck AO, Eizirik DL (2016) Viral infections in type 1 diabetes mellitus-why the $\beta$ cells? Nat Rev Endocrinol 12:263

16. Sarmiento L, Cubas-Dueñas I, Cabrera-Rode E (2013) Evidence of association between type 1 diabetes and exposure to enterovirus in Cuban children and adolescents. MEDICC Rev 15:29-32

17. Campbell IL, Kay T, Oxbrow L, Harrison L (1991) Essential role for interferon-gamma and interleukin-6 in autoimmune insulin-dependent diabetes in NOD/Wehi mice. J Clin Investig 87:739-742

18. Christen U, Edelmann KH, McGavern DB, Wolfe T, Coon B, Teague MK, Miller SD, Oldstone MB, Von Herrath MG (2004) A viral epitope that mimics a self antigen can accelerate but not initiate autoimmune diabetes. J Clin Investig 114:1290-1298

19. Principi N, Berioli MG, Bianchini S, Esposito S (2017) Type 1 diabetes and viral infections: what is the relationship? J Clin Virol 96:26-31

20. Yang J-K, Lin S-S, Ji X-J, Guo L-M (2010) Binding of SARS coronavirus to its receptor damages islets and causes acute diabetes. Acta Diabetol 47:193-199

21. Huang C, Wang Y, Li X, Ren L, Zhao J, Hu Y, Zhang L, Fan G, Xu J, Gu X (2020) Clinical features of patients infected with 2019 novel coronavirus in Wuhan, China. Lancet 395:497-506

22. Cao X (2020) COVID-19: immunopathology and its implications for therapy. Nat Rev Immunol 20:269

23. Qin C, Zhou L, Hu Z, Zhang S, Yang S, Tao Y, Xie C, Ma K, Shang K, Wang W (2020) Dysregulation of immune response in patients with COVID-19 in Wuhan, China. Clin Infect Dis

24. Ye Q, Wang B, Mao J (2020) The pathogenesis and treatment of the 'Cytokine Storm' in COVID-19. J Infect 80:607

25. Wu D, Yang XO (2020) TH17 responses in cytokine storm of COVID-19: an emerging target of JAK2 inhibitor Fedratinib. J Microbiol Immunol Infect 53:368

26. McGonagle D, Sharif K, O'Regan A, Bridgewood C (2020) the role of cytokines including interleukin-6 in COVID-19 induced pneumonia and macrophage activation syndrome-like disease. Autoimmun Rev. https://doi.org/10.1016/j.autrev.2020.102537 
27. Walker LS, von Herrath M (2016) CD4 T cell differentiation in type 1 diabetes. Clin Exp Immunol 183:16-29

28. Ferraro A, Socci C, Stabilini A, Valle A, Monti P, Piemonti L, Nano R, Olek S, Maffi P, Scavini M (2011) Expansion of Th17 cells and functional defects in T regulatory cells are key features of the pancreatic lymph nodes in patients with type 1 diabetes. Diabetes 60:2903-2913

29. Wilson NJ, Boniface K, Chan JR, McKenzie BS, Blumenschein WM, Mattson JD, Basham B, Smith K, Chen T, Morel F (2007) Development, cytokine profile and function of human interleukin 17-producing helper T cells. Nat Immunol 8:950-957

30. Reinert-Hartwall L, Honkanen J, Salo HM, Nieminen JK, Luopajärvi K, Härkönen T, Veijola R, Simell O, Ilonen J, Peet A (2015) Th1/Th17 plasticity is a marker of advanced $\beta$ cell autoimmunity and impaired glucose tolerance in humans. J Immunol 194:68-75

31. Abdel-Moneim A, Bakery HH, Allam G (2018) The potential pathogenic role of IL-17/Th17 cells in both type 1 and type 2 diabetes mellitus. Biomed Pharmacother 101:287-292

32. Shoelson SE, Herrero L, Naaz A (2007) Obesity, inflammation, and insulin resistance. Gastroenterology 132:2169-2180

33. Sell H, Habich C, Eckel J (2012) Adaptive immunity in obesity and insulin resistance. Nat Rev Endocrinol 8:709-716

34. Shoelson SE, Lee J, Goldfine AB (2006) Inflammation and insulin resistance. J Clin Investig 116:1793-1801

35. Jia G, Hill MA, Sowers JR (2018) Diabetic cardiomyopathy: an update of mechanisms contributing to this clinical entity. Circ Res 122:624-638. https://doi.org/10.1161/CIRCRESAHA.117. 311586

36. Bajpai A, Tilley DG (2018) The role of leukocytes in diabetic cardiomyopathy. Front Physiol 9:1547. https://doi.org/10.3389/ fphys.2018.01547

37. Lavoie JL, Sigmund CD (2003) Minireview: overview of the renin-angiotensin system-an endocrine and paracrine system. Endocrinology 144:2179-2183

38. Hitomi H, Kiyomoto H, Nishiyama A (2007) Angiotensin II and oxidative stress. Curr Opin Cardiol 22:311-315. https://doi.org/ 10.1097/HCO.0b013e3281532b53

39. Benigni A, Cassis P, Remuzzi G (2010) Angiotensin II revisited: new roles in inflammation, immunology and aging. EMBO Mol Med 2:247-257. https://doi.org/10.1002/emmm.201000080

40. Bindom SM, Lazartigues E (2009) The sweeter side of ACE2: physiological evidence for a role in diabetes. Mol Cell Endocrinol 302:193-202

41. Tipnis SR, Hooper NM, Hyde R, Karran E, Christie G, Turner $\mathrm{AJ}$ (2000) A human homolog of angiotensin-converting enzyme cloning and functional expression as a captopril-insensitive carboxypeptidase. J Biol Chem 275:33238-33243

42. Li W, Moore MJ, Vasilieva N, Sui J, Wong SK, Berne MA, Somasundaran M, Sullivan JL, Luzuriaga K, Greenough TC (2003) Angiotensin-converting enzyme 2 is a functional receptor for the SARS coronavirus. Nature 426:450-454

43. Gheblawi M, Wang K, Viveiros A, Nguyen Q, Zhong J-C, Turner AJ, Raizada MK, Grant MB, Oudit GY (2020) Angiotensin converting enzyme 2: SARS-CoV-2 receptor and regulator of the renin-angiotensin system. Circ Res 126:1456

44. Roca-Ho H, Riera M, Palau V, Pascual J, Soler MJ (2017) Characterization of ACE and ACE2 expression within different organs of the NOD mouse. Int J Mol Sci 18:563

45. Wong DW, Oudit GY, Reich H, Kassiri Z, Zhou J, Liu QC, Backx PH, Penninger JM, Herzenberg AM, Scholey JW (2007) Loss of angiotensin-converting enzyme-2 (Ace2) accelerates diabetic kidney injury. Am J Pathol 171:438-451

46. Santos SHS, Fernandes LR, Mario ÉG, Ferreira AVM, Pôrto LCJ, Alvarez-Leite JI, Botion LM, Bader M, Alenina N, Santos RAS (2008) Mas deficiency in FVB/N mice produces marked changes in lipid and glycemic metabolism. Diabetes 57:340-347
47. Echeverría-Rodríguez O, Del Valle-Mondragón L, Hong E (2014) Angiotensin 1-7 improves insulin sensitivity by increasing skeletal muscle glucose uptake in vivo. Peptides 51:26-30

48. Battiprolu PK, Gillette TG, Wang ZV, Lavandero S, Hill JA (2010) Diabetic cardiomyopathy: mechanisms and therapeutic targets. Drug Discov Today Dis Mech 7:e135-e143. https://doi. org/10.1016/j.ddmec.2010.08.001

49. Dostal DE (2000) The cardiac renin-angiotensin system: novel signaling mechanisms related to cardiac growth and function. Regul Pept 91:1-11. https://doi.org/10.1016/s0167-0115(99) 00123-8

50. Hernanz R, Martinez-Revelles S, Palacios R, Martin A, Cachofeiro V, Aguado A, Garcia-Redondo L, Barrus MT, de Batista PR, Briones AM, Salaices M, Alonso MJ (2015) Toll-like receptor 4 contributes to vascular remodelling and endothelial dysfunction in angiotensin II-induced hypertension. Br J Pharmacol 172:3159-3176. https://doi.org/10.1111/bph.13117

51. Fang L, Karakiulakis G, Roth M (2020) Are patients with hypertension and diabetes mellitus at increased risk for COVID-19 infection? Lancet Respir Med 8:e21. https://doi.org/10.1016/ S2213-2600(20)30116-8

52. Beger HG, Buchler M, Kozarek R, Lerch M, Neoptolemos JP, Warshaw A, Whitcomb D, Shiratori K (2009) The pancreas: an integrated textbook of basic science, medicine, and surgery. Wiley

53. Evans JL, Goldfine ID, Maddux BA, Grodsky GM (2003) Are oxidative stress-activated signaling pathways mediators of insulin resistance and $\beta$-cell dysfunction? Diabetes 52:1-8

54. Tikellis C, Wookey PJ, Candido R, Andrikopoulos S, Thomas MC, Cooper ME (2004) Improved islet morphology after blockade of the renin-angiotensin system in the ZDF rat. Diabetes 53:989-997

55. Niu M-J, Yang J-K, Lin S-S, Ji X-J, Guo L-M (2008) Loss of angiotensin-converting enzyme 2 leads to impaired glucose homeostasis in mice. Endocrine 34:56-61

56. Bindom SM, Hans $\mathrm{CP}$, Xia H, Boulares AH, Lazartigues E (2010) Angiotensin I-converting enzyme type 2 (ACE2) gene therapy improves glycemic control in diabetic mice. Diabetes 59:2540-2548

57. Chhabra KH, Xia H, Pedersen KB, Speth RC, Lazartigues E (2013) Pancreatic angiotensin-converting enzyme 2 improves glycemia in angiotensin II-infused mice. Am J Physiol Endocrinol Metab 304:E874-E884

58. Shoemaker R, Yiannikouris F, Thatcher S, Cassis L (2015) ACE2 deficiency reduces $\beta$-cell mass and impairs $\beta$-cell proliferation in obese C57BL/6 mice. Am J Physiol Endocrinol Metab 309:E621-E631

59. Wang J, Liu R, Qi H, Wang Y, Cui L, Wen Y, Li H, Yin C (2015) The ACE2-angiotensin-(1-7)-Mas axis protects against pancreatic cell damage in cell culture. Pancreas 44:266-272

60. Yu X, Cui L, Hou F, Liu X, Wang Y, Wen Y, Chi C, Li C, Liu $R$, Yin C (2018) Angiotensin-converting enzyme 2-angiotensin (1-7)-Mas axis prevents pancreatic acinar cell inflammatory response via inhibition of the $\mathrm{p} 38$ mitogen-activated protein kinase/nuclear factor-кB pathway. Int J Mol Med 41:409-420

61. Lu C-L, Wang Y, Yuan L, Li Y, Li X-Y (2014) The angiotensinconverting enzyme $2 /$ angiotensin (1-7)/Mas axis protects the function of pancreatic $\beta$ cells by improving the function of islet microvascular endothelial cells. Int J Mol Med 34:1293-1300

62. Hoffmann M, Kleine-Weber H, Schroeder S, Krüger N, Herrler T, Erichsen S, Schiergens TS, Herrler G, Wu N-H, Nitsche A (2020) SARS-CoV-2 cell entry depends on ACE2 and TMPRSS 2 and is blocked by a clinically proven protease inhibitor. Cell 181:271

63. Groß S, Jahn C, Cushman S, Bär C, Thum T (2020) SARSCoV-2 receptor ACE2-dependent implications on the 
cardiovascular system: from basic science to clinical implications. J Mol Cell Cardiol 144:47

64. Patel VB, Clarke N, Wang Z, Fan D, Parajuli N, Basu R, Putko B, Kassiri Z, Turner AJ, Oudit GY (2014) Angiotensin II induced proteolytic cleavage of myocardial ACE2 is mediated by TACE/ADAM-17: a positive feedback mechanism in the RAS. J Mol Cell Cardiol 66:167-176. https://doi.org/10. 1016/j.yjmcc.2013.11.017

65. Wang X, Oka T, Chow FL, Cooper SB, Odenbach J, Lopaschuk GD, Kassiri Z, Fernandez-Patron C (2009) Tumor necrosis factor-alpha-converting enzyme is a key regulator of agonist-induced cardiac hypertrophy and fibrosis. Hypertension 54:575-582. https://doi.org/10.1161/HYPERTENSIONAHA. 108.127670

66. Pedersen KB, Chodavarapu H, Porretta C, Robinson LK, Lazartigues E (2015) Dynamics of ADAM17-mediated shedding of ACE2 applied to pancreatic islets of male $\mathrm{db} / \mathrm{db}$ mice. Endocrinology 156:4411-4425

67. Kanat M, Winnier D, Norton L, Arar N, Jenkinson C, DeFronzo RA, Abdul-Ghani MA (2011) The relationship between $\beta$-cell function and glycated hemoglobin: results from the veterans administration genetic epidemiology study. Diabetes Care 34:1006-1010

68. Hou X, Liu J, Song J, Wang C, Liang K, Sun Y, Ma Z, Yang W, Li C, Zhang X (2016) Relationship of hemoglobin A1c with $\beta$ cell function and insulin resistance in newly diagnosed and drug naive type 2 diabetes patients. J Diabetes Res 20:16. https://doi. org/10.1155/2016/8797316

69. Marini M, Frontoni S, Succurro E, Arturi F, Sciacqua A, Hribal M, Perticone F, Sesti G (2014) Insulin sensitivity, and $\beta$-cell function in relation to hemoglobin A1C. Nutr Metab Cardiovasc Dis $24: 27-33$

70. Itzhaki Ben Zadok O, Kornowski R, Goldenberg I, Klempfner R, Toledano Y, Biton Y, Fisman EZ, Tenenbaum A, Golovchiner G, Kadmon E, Omelchenko A, Gal TB, Barsheshet A (2017) Admission blood glucose and 10-year mortality among patients with or without pre-existing diabetes mellitus hospitalized with heart failure. Cardiovasc Diabetol 16:102. https://doi.org/10. 1186/s12933-017-0582-y

71. Selvin E, Steffes MW, Zhu H, Matsushita K, Wagenknecht L, Pankow J, Coresh J, Brancati FL (2010) Glycated hemoglobin, diabetes, and cardiovascular risk in nondiabetic adults. $\mathrm{N}$ Engl $\mathrm{J}$ Med 362:800-811. https://doi.org/10.1056/NEJMoa0908359

72. Wang Z, Du Z, Zhu F (2020) Glycosylated hemoglobin is associated with systemic inflammation, hypercoagulability, and prognosis of COVID-19 patients. Diabetes Res Clin Pract 164:108214

73. Rubino F, Amiel SA, Zimmet P, Alberti G, Bornstein S, Eckel RH, Mingrone G, Boehm B, Cooper ME, Chai Z (2020) Newonset diabetes in Covid-19. N Engl J Med 383:789

74. Fernández-Real J-M, López-Bermejo A, Vendrell J, Ferri M-J, Recasens M, Ricart W (2006) Burden of infection and insulin resistance in healthy middle-aged men. Diabetes Care 29:1058-1064

75. Ren H, Yang Y, Wang F, Yan Y, Shi X, Dong K, Yu X, Zhang S (2020) Association of the insulin resistance marker TyG index with the severity and mortality of COVID-19. Cardiovasc Diabetol 19:1-8

76. Olivares-Reyes JA, Arellano-Plancarte A, Castillo-Hernandez JR (2009) Angiotensin II and the development of insulin resistance: implications for diabetes. Mol Cell Endocrinol 302:128-139

77. Ginsberg HN (2000) Insulin resistance and cardiovascular disease. J Clin Invest 106:453-458. https://doi.org/10.1172/JCI10 762

78. Zhou MS, Schulman IH, Raij L (2004) Nitric oxide, angiotensin II, and hypertension. Semin Nephrol 24:366-378. https://doi.org/ 10.1016/j.semnephrol.2004.04.008
79. Wu J, Huang J, Zhu G, Wang Q, Lv Q, Huang Y, Yu Y, Si X, Yi H, Wang C (2020) Elevation of blood glucose level predicts worse outcomes in hospitalized patients with COVID-19: a retrospective cohort study. BMJ Open Diabetes Res Care 8:1476

80. Wang S, Ma P, Zhang S, Song S, Wang Z, Ma Y, Xu J, Wu F, Duan L, Yin Z (2020) Fasting blood glucose at admission is an independent predictor for 28-day mortality in patients with COVID-19 without previous diagnosis of diabetes: a multi-centre retrospective study. Diabetologia 63:2102-2111

81. Ceriello A (2020) Hyperglycemia and COVID-19: what was known and what is really new? Diabetes Res Clin Pract 167:108

82. Zini E, Osto M, Franchini M, Guscetti F, Donath M, Perren A, Heller R, Linscheid P, Bouwman M, Ackermann M (2009) Hyperglycaemia but not hyperlipidaemia causes beta cell dysfunction and beta cell loss in the domestic cat. Diabetologia $52: 336$

83. Donath MY, Ehses JA, Maedler K, Schumann DM, Ellingsgaard $\mathrm{H}$, Eppler E, Reinecke M (2005) Mechanisms of $\beta$-cell death in type 2 diabetes. Diabetes 54:S108-S113

84. Zhou MS, Schulman IH, Zeng Q (2012) Link between the reninangiotensin system and insulin resistance: implications for cardiovascular disease. Vasc Med 17:330-341. https://doi.org/10. 1177/1358863X12450094

85. Roca-Ho H, Palau V, Gimeno J, Pascual J, Soler MJ, Riera M (2020) Angiotensin-converting enzyme 2 influences pancreatic and renal function in diabetic mice. Lab Invest 100:1169

86. Xuan X, Gao F, Ma X, Huang C, Wang Y, Deng H, Wang S, Li W, Yuan L (2018) Activation of ACE2/angiotensin (1-7) attenuates pancreatic $\beta$ cell dedifferentiation in a high-fat-diet mouse model. Metabolism 81:83-96

87. Fignani D, Licata G, Brusco N, Nigi L, Grieco GE, Marselli L, Overbergh L, Gysemans C, Colli ML, Marchetti P (2020) SARS-CoV-2 receptor angiotensin I-converting enzyme type 2 is expressed in human pancreatic islet $\beta$-cells and is upregulated by inflammatory stress. bioRxiv

88. Watanabe Y, Allen JD, Wrapp D, McLellan JS, Crispin M (2020) Site-specific glycan analysis of the SARS-CoV-2 spike. Science

89. Mehdipour AR, Hummer G (2020) Dual nature of human ACE2 glycosylation in binding to SARS-CoV-2 spike. bioRxiv

90. Grant OC, Montgomery D, Ito K, Woods RJ (2020) Analysis of the SARS-CoV-2 spike protein glycan shield: implications for immune recognition. bioRxiv

91. Brufsky A (2020) Hyperglycemia, hydroxychloroquine, and the COVID-19 pandemic. J Med Virol 92:770

92. Dokken BB (2008) The pathophysiology of cardiovascular disease and diabetes: beyond blood pressure and lipids. Diabetes Spectrum 21:160-165. https://doi.org/10.2337/diaspect.21.3.160

93. Dushpanova A, Agostini S, Ciofini E, Cabiati M, Casieri V, Matteucci M, Del Ry S, Clerico A, Berti S, Lionetti V (2016) Gene silencing of endothelial von Willebrand Factor attenuates angiotensin II-induced endothelin-1 expression in porcine aortic endothelial cells. Sci Rep 6:30048. https://doi.org/10.1038/srep3 0048

94. Peng X, Wang X, Fan M, Zhao J, Lin L, Liu J (2020) Plasma levels of von Willebrand factor in type 2 diabetes patients with and without cardiovascular diseases: a meta-analysis. Diabetes Metab Res Rev 36:e3193. https://doi.org/10.1002/dmrr.3193

95. Chen J, Wang X, Zhang S, Liu B, Wu X, Wang Y, Wang X, Yang M, Sun J, Xie Y (2020) Findings of acute pulmonary embolism in COVID-19 patients. SSRN 3548771

96. Jose RJ, Manuel A (2020) COVID-19 cytokine storm: the interplay between inflammation and coagulation. Lancet Respir Med 8:e46

97. Zheng KI, Gao F, Wang XB, Sun QF, Pan KH, Wang TY, Ma HL, Chen YP, Liu WY, George J, Zheng MH (2020) Letter to the editor: obesity as a risk factor for greater severity of COVID-19 
in patients with metabolic associated fatty liver disease. Metabolism 108:154244. https://doi.org/10.1016/j.metabol.2020.154244

98. Caussy C, Pattou F, Wallet F, Simon C, Chalopin S, Telliam C, Mathieu D, Subtil F, Frobert E, Alligier M, Delaunay D, Vanhems P, Laville M, Jourdain M, Disse E, Consortium COH and Lille C-OSG (2020) Prevalence of obesity among adult inpatients with COVID-19 in France. Lancet Diabetes Endocrinol 8:562-564. https://doi.org/10.1016/S2213-8587(20)30160-1

99. Zhou Y, Chi J, Lv W, Wang Y (2020) Obesity and diabetes as high-risk factors for severe coronavirus disease 2019 (Covid-19). Diabetes Metab Res Rev. https://doi.org/10.1002/dmrr.3377

100. Li B, Yang J, Zhao F, Zhi L, Wang X, Liu L, Bi Z, Zhao Y (2020) Prevalence and impact of cardiovascular metabolic diseases on COVID-19 in China. Clin Res Cardiol 109:531-538. https://doi. org/10.1007/s00392-020-01626-9

101. Cheng Y, Luo R, Wang K, Zhang M, Wang Z, Dong L, Li J, Yao Y, Ge S, Xu G (2020) Kidney disease is associated with in-hospital death of patients with COVID-19. Kidney Int 97:829-838. https://doi.org/10.1016/j.kint.2020.03.005

102. Tadic M, Cuspidi C, Mancia G, Dell'Oro R, Grassi G (2020) COVID-19, hypertension and cardiovascular diseases: should we change the therapy? Pharmacol Res 158:104906. https://doi.org/ 10.1016/j.phrs.2020.104906

103. Awortwe C, Cascorbi I (2020) Meta-analysis on outcome-worsening comorbidities of COVID-19 and related potential drugdrug interactions. Pharmacol Res. https://doi.org/10.1016/j.phrs. 2020.105250

104. Razeghian-Jahromi I, Zibaeenezhad MJ, Lu Z, Zahra E, Mahboobeh R, Lionetti V (2021) Angiotensin-converting enzyme 2: a double-edged sword in COVID-19 patients with an increased risk of heart failure. Heart Fail Rev 26:371-380. https://doi.org/ 10.1007/s10741-020-10016-2

105. Dolhnikoff M, Ferreira Ferranti J, de Almeida Monteiro RA, Duarte-Neto AN, Soares Gomes-Gouvea M, Viu Degaspare N, Figueiredo Delgado A, Montanari Fiorita C, Nunes Leal G, Rodrigues RM, Taverna Chaim K, Rebello Pinho JR, Carneiro-Sampaio M, Mauad T, Ferraz da Silva LF, Brunow de Carvalho W, Saldiva PHN, Garcia Caldini E (2020) SARS-CoV-2 in cardiac tissue of a child with COVID-19-related multisystem inflammatory syndrome. Lancet Child Adolesc Health 4:790-794. https:// doi.org/10.1016/S2352-4642(20)30257-1

106. Li M, Dong Y, Wang H, Guo W, Zhou H, Zhang Z, Tian C, Du K, Zhu R, Wang L, Zhao L, Fan H, Luo S, Hu D (2020) Cardiovascular disease potentially contributes to the progression and poor prognosis of COVID-19. Nutr Metab Cardiovasc Dis 30:1061-1067. https://doi.org/10.1016/j.numecd.2020.04.013

107. Nishiga M, Wang DW, Han Y, Lewis DB, Wu JC (2020) COVID19 and cardiovascular disease: from basic mechanisms to clinical perspectives. Nat Rev Cardiol 17:543-558. https://doi.org/10. 1038/s41569-020-0413-9

Publisher's Note Springer Nature remains neutral with regard to jurisdictional claims in published maps and institutional affiliations. 